\title{
PENGARUH PEMBERIAN KARBOL SEBAGAIDESINFEKTAN TERHADAP JUMLAH ANGKA KUMAN PADA LANTAI RUANG PARIKESIT KELAS III RUMAH SAKIT TK III.04.06.01 WIJAYAKUSUMA PURWOKERTO TAHUN 2017
}

\author{
Stylla Vonch Emdiyono ${ }^{1)}$, Budi Triyantoro ${ }^{2)}$ \\ Jurusan Kesehatan Lingkungan, Politeknik Kesehatan Kemenkes Semarang, \\ Jl.Raya Baturaden KM 12 Purwokerto, Indonesia
}

\begin{abstract}
Abstrak
Pasien di rumah sakit sangat rentan terhadap penyakit, sehingga kebersihan lantai rumah sakit perlu diperhatikan. Lantai rumah sakit yang kotor menjadi tempat pertumbuhan mikroorganisme patogen, maka dari itu perlu dilakukan pelaksanaan desinfeksi dengan menggunakan desinfektan. Desinfektan merupakan bahan kimia yang digunakan untuk membunuh mikroorganisme patogen. Apabila desinfektan dosisnya kurang efektif, kemungkinan mempengaruhi pertumbuhan mikroorganisme yang ada di lantai rumah sakit.Metode yang digunakan dalam penelitian ini adalah penelitian analitik. Pengumpulan data dengan cara observasi, wawancara, pengukuran, pemeriksaan dan perhitungan jumlah kuman. Data dalam penelitian disajikan dalam bentuk tabel dan narasi. Analisis data yang digunakan adalah uji $t$ test (pre-post). Hasil penelitian ini menunjukkan bahwa jumlah kuman pada lantai Ruang Parikesit Kelas III belum memenuhi standar yang disyaratkan, berdasarkan Kepmenkes RI No.1204/Menkes/SK/X/2004, yaitu 5-10 koloni $/ \mathrm{cm}^{2}$ dan hasil penelitian pada Ruang Parikesit Kelas III, yaitu sebelum pemberian desinfektan memiliki rata-rata mencapai 314,8 koloni $/ \mathrm{cm}^{2}$ dan sesudah pemberian desinfektan memiliki rata-rata mencapai $22,8 \mathrm{koloni} / \mathrm{cm}^{2}$.Kesimpulan dari penelitian ini adalah pemberian desinfektan pada saat pengepelan dapat menghambat perkembangan jumlah kuman pada lantai.
\end{abstract}

Kata kunci:rumah sakit; kuman lantai; desinfektan;kesehatan lingkungan

\begin{abstract}
THE EFFECTIFNESS OF GIVING CARBOL AS A DESINFECTANT TOWARD THE NUMBER OF MICROBE ON THE FLOOR OF PARIKESIT THIRD CLASS ROOM OF WIJAYAKUSUMA THIRD LEVEL 04.06.01 HOSPITAL OF PURWOKERTO YEAR 2017. Hospital's patients are very suspectible to illness, with the result that the sanitation of the hospital's floor need to be noticed. Dirty floor can be place for patogen microorganism to grow, then it is needed a cleaning using disinfectant. Disinfectant is a chemical substant used to exterminate patogen microorganism. if disinfectant's dose is not effective enough, it may influence the growth of microorganism on the hospital's floor. The method which was used in this research is analytical research. Data collection which were used are observation, interview, measuring, examination and calculation of the number of microbe. The data is presented in the form of table and naration. This research used $t$-test as a data analysis. The result of t-test shows that there is difference of microbe's number before and after giving disinfectant. The result of this research shows that the number of microbe hasn't fullfiled the standard which is required. Based on Kemenkes RI no. 1204/ Menkes/SK/X/ that is 5-10coloni/ $\mathrm{cm}^{2}$ and the result of the research in parikesit third class room shows the average of the number of microbbe reach out for 314, $8 \mathrm{coloni} / \mathrm{cm}^{2}$ before and 22,8 coloni/ $\mathrm{cm}^{2}$ after giving disinfectant.The conclusion of this research is the giving of disinfectant in the mopping floor can hamper the growth of the number of microbe on the floor.
\end{abstract}

Keywords:Hospital; Microbre's floor; Disinfectant; Environtment Health 


\section{Pendahuluan}

Pembangunan yang dilaksanakan di Indonesia salah satunya adalah pembangunan bidang kesehatan. Pembangunan kesehatan bertujuan untuk meningkatkan kesadaran, kemauan, dan kemampuan hidup sehat bagi setiap orang agar terwujud derajat kesehatan masyarakat yang setinggi tingginya, sebagai investasi pembangunan, bagi sumber daya manusia yang produktif secara sosial dan ekonomis. (Undang - undang kesehatan No 36 pasal 3 tahun 2009).

Perilaku masyarakat Indonesia era saat ini adalah perilaku proaktif untuk memelihara dan meningkatkan kesehatan, mencegah risiko terjadinya penyakit, melindungi diri dari ancaman penyakit serta berpartisipasi aktif dalam gerakan kesehatan masyarakat.Masyarakat diharapkan mempunyai kemampuan untuk menjangkau pelayanan kesehatan yang bermutu.Pelayanan kesehatan yang tersedia adalah pelayanan yang berhasil guna dan berdaya guna yang tersebar merata di seluruh Indonesia, salah satu pelayanan kesehatan itu sendiri adalah rumah sakit.

Rumah sakit sebagai salah satu institusi pelayanan kesehatan dengan upaya pencegahan penyakit (preventive),penyembuhan penyakit (curative), pemulihan penderita(rehabilitative)dan peningkatan kesehatan (promotive). Kegiatan tersebut menimbulkan dampak positif dan negatif, dampak positifnya adalah meningkatnya derajat kesehatan masyarakat, sedangkan dampak negatif adalah agen penyakit yang dibawa oleh penderita dari luar rumah sakit atau pengunjung yang berstatus karier. Aspek sanitasi rumah sakit yang harus diperhatikan dalam tata cara pelaksanaan kegiatan penyehatan lingkungan rumah sakit adalah penyehatan ruang danbangunantermasukpencahayaan, penghawaan,kebisingan dan fasilitas sanitasi. Lingkungan, ruang dan bangunan rumah sakit harus selalu dalam keadaan bersih dan tersedia fasilitas sanitasi secara kualitas dan kuantitas yang memenuhi persyaratan kesehatan, sehingga tidak memungkinkan sebagai tempat bersarang dan berkembangbiaknya serangga, binatang pengerat dan binatang pengganggu.

Rumah Sakit TK III 04.06.01 Wijayakusuma merupakan rumah sakit yang dikelola oleh Tentara Nasional Indonesia Angkatan Darat.Rumah sakit ini mempunyai beberapa bangsal diantaranya, yaitu bangsal Antasena, Gayatri, Parikesit, Srikandi, Cakra, Paviliun Bima, Paviliun Kresna, Paviliun Abimanyu. Menurut data bulan Desember 2016 Rumah Sakit TK III 04.06.01 Wijayakusuma mempunyai jumlah tempat tidur sebanyak 150 tempat tidur dan memiliki angka BOR (Bed Occupancy Rate/ prosentase pemakaian tempat tidur) 80\%, karena terdapat beberapa bangsal yang banyak pengunjung, sehingga dapat menimbulkan

\footnotetext{
${ }^{1)}$ E-mail: styllavonch1@gmail.com

${ }^{2)}$ E-mail: buditri1309@gmail.com
}

lingkungan rumah sakit menjadi tidak sehat, seperti lantai ruangan menjadi kotor, banyak sampah, dan permasalahan yang lain.

Ruang Parikesit merupakan ruang khusus penderita yang masih anak - anak, sehingga pada umumnya anak - anak yang dirawat selalu ditunggu oleh beberapa orang yang selalu silih berganti. Ruang Parikesit memiliki aturan jam kunjung pasien dari pagi sampai sore, sedangkan malam tidak diperkenankan, karena untuk beristirahat. Dengan padatnya aktivitas penunggu dan pengunjung kemungkinan Infeksi Nosokomial dapat terjadi.

Menurut Kepmenkes RI Nomor: 1204/ Menkes/SK/X/2004 tentang Persyaratan Kesehatan Lingkungan Rumah Sakit menyebutkan bahwa lantai rumah sakit harus selalu bersih dan angka kuman lantai yang diperbolehkan di ruang operasi 0-5 koloni/ $\mathrm{cm}^{2}$ dan ruang perawatan 5-10 koloni/ $\mathrm{cm}^{2}$. Pada penyehatan ruang dan bangunan rumah sakit syarat lantai rumah sakit adalah lantai harus terbuat dari bahan yang kuat, kedap air, permukaan rata dan mudah dibersihkan.

Lantai yang kotor perlu dilakukan pelaksanaan desinfeksi. Menurut Sanropie (1989) desinfeksi adalah upaya untuk mengurangi/ menghilangkan jumlah mikroorganisme patogen penyebab penyakit (tidak termasuk spora) dengan cara kimiawi. Pengepelan menggunakan desinfektan adalah usaha untuk membersihkan lantai dengan cara kimiawi untuk mengurangi dan menghilangkan mikroorganisme patogen penyebab penyakit. Dalam hal ini, yang perlu diperhatikan adalah desinfektan yang efektif sehingga dapat tercapai daya bunuh yang optimal pada kuman. Bahan kimia yang digunakan untuk mencegah terjadinya infeksi atau pencemaran jasad renik dan untuk membunuhataumenurunkanjumlah mikroorganisme disebutdesinfektan. Efektifitas desinfektan dapat diuji langsung dengan cara sebelum dan setelah lantai diberi bahan desinfektan kemudian dihitung jumlah angka kuman yang ada di lantai tersebut (Kepmenkes RI, 2004).

Pasien yang daya tahan tubuhnya rendah seharusnya dihindarkan dari infeksi kuman di ruangan rumah sakit. Langkah-langkah yang harus dilakukan adalah menekan risiko terjadinya infeksi, yang dilakukan dengan kaidah sepsis dan antisepsis serta perubahan tindakan perawat dan dokter yang bekerja dirumah sakit. Faktor yang paling penting disini adalah sanitasi lingkungan sekitar rumah sakit. Salah satu faktor yang perlu diperhatikan dalam rangka menurunkan kasus penularan penyakit infeksi di rumah sakit adalah desinfeksi terhadap seluruh aspek yang terkait dalam pelayanan pasien, termasuk lantai rumah sakit. Penyakit infeksi yang terjadi di rumah sakit selama seseorang dirawat atau setelah selesai dirawat disebut dengan Infeksi Nosokomial. 
Infeksi Nosokomial dapat berasal dari dalam tubuh penderita maupun luar tubuh. Mikroorganisme Infeksi Nosokomial dapat hidup dan berkembang di lingkungan rumah sakit, seperti : udara, air, makanan, lantai, dan benda- benda medis maupun non medis. Penularan Infeksi Nosokomial melalui lantai disebabkan oleh bakteri, contohnya adalah Staphylococcus aereus, bakteri tersebut biasanya tinggal ditempat yang lembab, sehingga apabila lantai dalam keadaan kotor dan tidak diberi desinfeksi maka perkembangan bakteri yang ada di lantai berkembang dengan cepat. Pravalensi Infeksi Nosokomial dari masing-masing rumah sakit sangat bervariasi. Surveilans yang pernah dilakukan Badan Kesehatan Dunia (WHO) di lima puluh lima rumah sakit di Asia Tenggara, Eropa, Mediterania dan Pasifik pada tahun 1987 sebanyak 8,7\% pasien yang dirawat di rumah sakit mengalami Infeksi Nosokomial (WHO,2002). Dari 4 region tersebut, Asia Tenggara dengan besaran kasus 10\% menjadi region tertinggi kasus Infeksi Nosokmial. Angka terendah ada di Eropa, dengan jumlah kasus 7,7 \% (Ducel et al., 2002). Insiden Infeksi Nosokmial di Amerika Serikat $\pm 5 \%$, di Malaysia prevalensinya $\pm 12,7 \%$, di Taiwan $\pm 13,8 \%$ (Hasyim, 2005).

Berdasarkan survei pendahuluan, bahwa tempat tidur Ruang Parikesit Kelas III hampir setiap hari dihuni oleh pasien, penunggu dan dikunjungi oleh keluarga pasien. Sering dijumpai, pengunjung, keluarga pasien, serta petugas kesehatan tidak melepas sandal saat masuk ke ruangan rawat inap, selain itu, keluarga pasien juga tidur dibawah tempat tidur pasien dengan menggunakan tikar sebagai alas.

\section{Bahan dan Metode}

Jenis penelitian yang dipakai adalah penelitian observasional analitik dengan pendekatan crossectional, yaitu mengambil kesimpulan/ menguraikan populasi yang sedang diteliti dengan didasarkan hasil penyelidikan sampel di Ruang Parikesit Kelas III Rumah Sakit TK III 04.06.01 Wijayakusuma Purwokerto.Metode pengambilan sampel yang digunakan adalah metode purposive sampling.Maksud dari purposive sampling, yaitu teknik pengambilan sampel disesuaikan dengan tujuan peneliti menurut tujuan penelitian, dengan pertimbangan berdasarkan ciri, sifat dan populasi yang sudah diketahui sebelumnya. Sampel diambil sebelum dan sesudah pemberian desinfektan 9 titik lantai yang sama pada Ruang Parikesit Kelas III saat pengepelan pertama pukul 07.00 WIB dan pengepelan kedua pukul 13.00 WIB. Masingmasing sampel diambil pada bagian lantai yang sering dilalui oleh orang yang berada di Ruang Parikesit kelas III, yaitu bagian pintu masuk Ruang Parikesit Kelas III, selain tempat tidur pasien diambil 6 titik, titik tengah ruangan, dan depan pintu kamar mandi Ruang Parikesit kelas III sebagai sampel yang diperiksa, jadi jumlah keseluruhan pengambilan sampel adalah 27 sampel $(\mathrm{n}<30$ ). Pengumpulan data dilakukan dengan cara observasi, studi dokumen, pengukuran suhu, kelembaban, pencahayaan, wawancara, pemeriksaan dan perhitungan angka kuman lantai. Instrumen yang digunakan berupa thermometer, hygrometer, luxmeter, checklist, metode swab, kuisioner, dan pemeriksaan laboratorium.

\section{Hasil dan Pembahasan}

Bedasarkan hasil penelitian terhadap angka kuman lantai yang telah dilaksanakan selama dua hari pada tanggal 2 dan 3 Mei 2017 di Ruang Parikesit Kelas III Rumah Sakit TK III 04.06.01 Wijayakusuma Purwokerto, dapat dilihat sebagai berikut :

a. Gambaran Umum Rumah Sakit

Rumah Sakit Wijayakusuma Purwokerto dahulu pada tahun 1949 bernama Rumah Sakit Brigade 8/III Sunan Gunung Jati, merupakan Rumah Sakit Belanda yang diserahkan ke Devisi II Sunan Gunung Jati. Pada tahun 1986 berdasarkan Surat Perintah Kepala Kesdam IV/ Diponegoro Nomor : Sprin 024/II/1986, Rumah Sakit Brigade 8/III Sunan Gunung Jati diubah menjadi Rumkit TK III/711 dan sekarang bernama Rumah Sakit TK III 04.06.01 Wijayakusuma Purwokerto.Rumah Sakit Wijayakusuma Purwokerto adalah Rumah Sakit Tk. III yang merupakan badan pelaksana fungsi teknis kesehatan di Wilayah Korem dan saat ini sudah dibuka untuk pasien umum. Indikator pelayanan rumah sakit dapat dilihat dari angka BOR (Bed Occupancy Rate) yaitu prosentase pemakaian tempat tidur pada satuan waktu tertentu (Depkes RI, 2005). Angka BOR untuk Rumah Sakit Wijayakusuma yaitu 80\%. Rumah Sakit TK III 04.06.01 Wijayakusuma Purwokerto mempunyai 150 tempat tidur yang setiap harinya rata-rata diisi oleh 120 pasien.

b. Deskripsi ruang Parikesit

Ruang Parikesit merupakan bangsal khusus anakanak yang mempunyai 3 kelas, yaitu kelas I, kelas II, dan kelas III, sedangkan yang peneliti ambil untuk penelitian, yaitu hanya Ruang Parikesit Kelas III.

Ruang Parikesit Kelas III mempunyai lebar 8,79 m, panjang $13,75 \mathrm{~m}$, dan tinggi $3 \mathrm{~m}$, dengan luas yaitu 120,86 m2 dan volume ruangan 362,58 m2. Ruang Parikesit Kelas III memiliki 12 tempat tidur dan terdapat 2 kamar mandi. Saat melakukan penelitian, pasien yang dirawat di Ruang Parikesit Kelas III berjumlah 10 orang dan suasana yang ada di Ruang Parikesit Kelas III ramai, karena banyak pengunjung yang datang menjenguk pasien. Berdasarkan hasil penilaian skore minimal upaya Kesehatan Lingkungan untuk ruang perawatan, yaitu $97 \%$. Hasil tersebut telah memenuhi syarat, karena penilaian Kesehatan Lingkungan untuk ruang perawatan $>75 \%$. 
c. Hasil Pengukuran

1) Suhu

Tabel 1. Hasil Pengukuran Suhu Ruang Parikesit Kelas III

\begin{tabular}{llcc}
\hline \multirow{2}{*}{ No. } & Waktu & \multicolumn{2}{c}{$\begin{array}{c}\text { Hasil Pemeriksaan Suhu } \\
\left({ }^{\circ} \mathrm{C}\right)\end{array}$} \\
\cline { 3 - 4 } & $\begin{array}{l}\text { Pengambilan } \\
\text { Sampel }\end{array}$ & $\begin{array}{c}\text { Sebelum } \\
\text { Pemberian } \\
\text { Desinfektan }\end{array}$ & $\begin{array}{c}\text { Sesudah } \\
\text { Pemberian } \\
\text { Desinfektan }\end{array}$ \\
\hline 1. & Pagi, 2 Mei 2017 & 23 & 23 \\
2. & Siang, 2 Mei 2017 & 24 & 25 \\
3. & Pagi, 3 Mei 2017 & 23 & 24 \\
\hline
\end{tabular}

Tabel 1. menjelaskan bahwa Ruang Parikesit Kelas III termasuk dalam kriteria memenuhi syarat, karena menurut Kepmenkes RI No. 1204/Menkes/SK/X/2004 tentang Persyaratan Kesehatan Lingkungan Rumah Sakit yang menerangkan bahwa suhu di ruang perawatan distandarkan $22^{\circ} \mathrm{C}-24^{\circ} \mathrm{C}$. Menurut Nyoman Suendra, et. al (1991, h.35), beberapa spesies dari bakteri dapat tumbuh pada suhu $0^{\circ} \mathrm{C}$, sedangkan spesies yang lainnya ada yang tumbuh pada suhu yang ekstrim yaitu $90^{\circ} \mathrm{C}$ atau lebih. Pada umumnya bakteri tumbuh pada batas kedua batas ekstrim tersebut $\left(0-90^{\circ} \mathrm{C}\right)$, jadi dengan suhu dibawah $25^{\circ} \mathrm{C}$ pada Ruang Parikesit Kelas III Rumah Sakit Wijayakusuma Purwokerto merupakan suhu yang baik bagi pertumbuhan bakteri.

2) Kelembaban

Tabel 2. Hasil Pengukuran Kelembaban

\begin{tabular}{|c|c|c|c|}
\hline \multirow[b]{2}{*}{ No. } & \multirow[b]{2}{*}{$\begin{array}{c}\text { Waktu Pengambilan } \\
\text { Sampel }\end{array}$} & \multicolumn{2}{|c|}{$\begin{array}{l}\text { Hasil Pemeriksaan } \\
\text { Kelembaban (\%) }\end{array}$} \\
\hline & & $\begin{array}{c}\text { Sebelum } \\
\text { Pemberian } \\
\text { Desinfektan }\end{array}$ & $\begin{array}{c}\text { Sesudah } \\
\text { Pemberian } \\
\text { Desinfektan }\end{array}$ \\
\hline 1. & Pagi, 2 Mei 2017 & 58 & 58 \\
\hline 2. & Siang, 2 Mei 2017 & 47 & 46 \\
\hline 3. & Pagi, 3 Mei 2017 & 57 & 58 \\
\hline
\end{tabular}

Tabel 2. menjelaskan bahwa kelembaban Ruang Parikesit Kelas III pada saat dilakukan penelitian pada pagi hari paling tinggi mencapai 58 \%,sedangkan siang hari kelembabannya paling tinggi mencapai $47 \%$ menurut Kepmenkes RI tentang Persyaratan Kesehatan Lingkungan Rumah Sakit, kelembaban di ruang perawatan distandarkan 45 - 60 \%, jadi nilai kelembaban pada saat penelitian sudah memenuhi standar.Menurut Depkes RI (1996, h. 23) udara ruang yang terlalu lembab dapat menyebabkan tumbuhnya bermacam- macam jamur dan spora. Udara yang terlalu kering menyebabkan keringnya lapisan mukosa dan merupakan pre disposisi infeksi saluran pernafasan atas. Kelembaban ruangan dapat berpengaruh terhadap mikroorganisme yang ada di lantai, tetapi mikroorganisme tersebut dapat hidup dan berkembang tidak hanya tergantung kepada kelembaban ruangan saja, tetapi lebih membutuhkan unsur-unsur yang lain.
3) Pencahayaan Ruangan

Tabel 3. Hasil Pengukuran Pencahayaan

\begin{tabular}{|c|c|c|c|}
\hline \multirow[b]{2}{*}{ No. } & \multirow{2}{*}{$\begin{array}{c}\text { Waktu } \\
\text { Pengambilan } \\
\text { Sampel }\end{array}$} & \multicolumn{2}{|c|}{$\begin{array}{l}\text { Hasil Pemeriksaan } \\
\text { Pencahayaan (Lux) }\end{array}$} \\
\hline & & $\begin{array}{c}\text { Sebelum } \\
\text { Pemberian } \\
\text { Desinfektan }\end{array}$ & $\begin{array}{c}\text { Sesudah } \\
\text { Pemberian } \\
\text { Desinfektan }\end{array}$ \\
\hline 1. & Pagi, 2 Mei 2017 & 182 & 183 \\
\hline 2. & Siang, 2 Mei 2017 & 103 & 100 \\
\hline 3. & Pagi, 3 Mei 2017 & 102 & 100 \\
\hline
\end{tabular}

Parikesit Kelas III termasuk dalam kriteria memenuhi syarat, karena menurut Kepmenkes RI No. 1204/Menkes/SK/X/2004tentang Persyaratan Kesehatan Lingkungan Rumah Sakit yang menerangkan bahwa pencahayaan di ruang perawatan distandarkan 100-200 lux.Pencahayaan ruangan yang dimaksud adalah pencahayaan alami pada waktu pukul 08.00 sampai 11.00 WIB, yaitu saat dilaksanakan pembersihan ruangan. Pencahayaan yang lebih terang mengakibatkan petugas kebersihan dapat lebih teliti dalam upaya menghilangkan sampah yang sebagai tempat hidup dan makanan mikroorganisme. Menurut Michael J Pelczar (1988, h. 232) pencahayaan alami juga dapat sebagai desinfektan bagi jenis mikroba tertentu, seperti kuman TBC.

4)Pengambilan Sampel Angka Kuman Lantai

Saat pengambilan sampel angka kuman pada pagi hari tanggal 2 Mei 2017 pada lokasi titik 1 didapatkan angka kuman sebelum pemberian desinfektan, yaitu 28 koloni $/ \mathrm{cm}^{2}$ dan sesudah pemberian desinfektan, yaitu 39 koloni $/ \mathrm{cm}^{2}$, selisih $-11 \mathrm{koloni} / \mathrm{cm}^{2}$, prosentase $-39,2 \%$, pada lokasi titik 2 didapatkan angka kuman sebelum pemberian desinfektan, yaitu $9 \mathrm{koloni} / \mathrm{cm}^{2}$ dan sesudah pemberian desinfektan, yaitu $18 \mathrm{koloni} / \mathrm{cm}^{2}$, selisih -9 koloni $/ \mathrm{cm}^{2}$, prosentase $-100 \%$, pada lokasi titik 3 didapatkan angka kuman sebelum pemberian desinfektan, yaitu $4 \mathrm{koloni} / \mathrm{cm}^{2}$ dan sesudah pemberian desinfektan, yaitu $14 \mathrm{koloni} / \mathrm{cm}^{2}$, selisih $-9 \mathrm{koloni} / \mathrm{cm}^{2}$, prosentase $-100 \%$, pada lokasi titik 4 didapatkan angka kuman sebelum pemberian desinfektan, yaitu 31 koloni $/ \mathrm{cm}^{2}$ dan sesudah pemberian desinfektan, yaitu 19 koloni $/ \mathrm{cm}^{2}$, selisih $12 \mathrm{koloni} / \mathrm{cm}^{2}$, prosentase 38,7 \%, pada lokasi titik 5 didapatkan angka kuman sebelum pemberian desinfektan, yaitu $5 \mathrm{koloni} / \mathrm{cm}^{2}$ dan sesudah pemberian desinfektan, yaitu $12 \mathrm{koloni} / \mathrm{cm}^{2}$, selisih -7 koloni $/ \mathrm{cm}^{2}$, prosentase $-140 \%$, pada lokasi titik 6 didapatkan angka kumansebelum pemberian desinfektan, yaitu $7 \mathrm{koloni} / \mathrm{cm}^{2}$ dan sesudah pemberian desinfektan, yaitu $19 \mathrm{koloni} / \mathrm{cm}^{2}$, selisih $-12 \mathrm{koloni} / \mathrm{cm}^{2}$, prosentase $-171,4 \%$, pada lokasi titik 7 didapatkan angka kuman sebelum pemberian desinfektan, yaitu 3 koloni $/ \mathrm{cm}^{2}$ dan sesudah pemberian desinfektan, yaitu 15 koloni $/ \mathrm{cm}^{2}$, selisih -12 koloni $/ \mathrm{cm}^{2}$, prosentase $-400 \%$, pada lokasi titik 8 didapatkan angka kuman sebelum pemberian desinfektan, yaitu $24 \mathrm{koloni} / \mathrm{cm}^{2}$ dan sesudah 
pemberian desinfektan, yaitu $44 \mathrm{koloni} / \mathrm{cm}^{2}$, selisih -20 koloni $/ \mathrm{cm}^{2}$, prosentase $-83,3 \%$, pada lokasi titik 9 didapatkan angka kuman sebelum pemberian desinfektan, yaitu $60 \mathrm{koloni} / \mathrm{cm}^{2}$ dan sesudah pemberian desinfektan, yaitu $6 \mathrm{koloni} / \mathrm{cm}^{2}$, selisih $54 \mathrm{koloni} / \mathrm{cm}^{2}$, prosentase $90 \%$, dan saat pengambilan sampel angka kuman pada siang hari tanggal 2 Mei 2017 pada lokasi titik 1 didapatkan angka kuman sebelum pemberian desinfektan, yaitu 6 koloni $/ \mathrm{cm}^{2}$ dan sesudah pemberian desinfektan, yaitu $4 \mathrm{koloni} / \mathrm{cm}^{2}$, selisih $2 \mathrm{koloni} / \mathrm{cm}^{2}$, prosentase 33,3 \% , pada lokasi titik 2 didapatkan angka kuman sebelum pemberian desinfektan, yaitu 18 koloni/ $/ \mathrm{cm}^{2}$ dan sesudah pemberian desinfektan, yaitu 5 koloni $/ \mathrm{cm}^{2}$, selisih $13 \mathrm{koloni} / \mathrm{cm}^{2}$, prosentase $72,2 \%$, pada lokasi titik 3 didapatkan angka kuman sebelum pemberian desinfektan, yaitu $26 \mathrm{koloni} / \mathrm{cm}^{2}$ dan sesudah pemberian desinfektan, yaitu $8 \mathrm{koloni} / \mathrm{cm}^{2}$, selisih 18 koloni $/ \mathrm{cm}^{2}$, prosentase $69,2 \%$, pada lokasi titik 4 didapatkan angka kuman sebelum pemberian desinfektan, yaitu $8 \mathrm{koloni} / \mathrm{cm}^{2}$ dan sesudah pemberian desinfektan, yaitu $5 \mathrm{koloni} / \mathrm{cm}^{2}$, selisih $3 \mathrm{koloni} / \mathrm{cm}^{2}$, prosentase $37,5 \%$, pada lokasi titik 5 didapatkan angka kuman sebelum pemberian desinfektan, yaitu 9 koloni $/ \mathrm{cm}^{2}$ dan sesudah pemberian desinfektan, yaitu 7 koloni $/ \mathrm{cm}^{2}$, selisih $2 \mathrm{koloni} / \mathrm{cm}^{2}$, prosentase 22,2\%, pada lokasi titik 6 didapatkan angka kuman sebelum pemberian desinfektan, yaitu $16 \mathrm{koloni} / \mathrm{cm}^{2}$ dan sesudah pemberian desinfektan, yaitu $5 \mathrm{koloni} / \mathrm{cm}^{2}$, selisih 11 koloni $/ \mathrm{cm}^{2}$, prosentase $68,7 \%$, pada lokasi titik 7 didapatkan angka kuman sebelum pemberian desinfektan, yaitu $6 \mathrm{koloni} / \mathrm{cm}^{2}$ dan sesudah pemberian desinfektan, yaitu $12 \mathrm{koloni} / \mathrm{cm}^{2}$, selisih $-6 \mathrm{koloni} / \mathrm{cm}^{2}$, prosentase $-100 \%$, pada lokasi titik 8 didapatkan angka kuman sebelum pemberian desinfektan, yaitu 33 koloni $/ \mathrm{cm}^{2}$ dan sesudah pemberian desinfektan, yaitu 20 koloni $/ \mathrm{cm}^{2}$, selisih $13 \mathrm{koloni} / \mathrm{cm}^{2}$, prosentase $39,3 \%$, pada lokasi titik 9 didapatkan angka kuman sebelum pemberian desinfektan, yaitu $25 \mathrm{koloni} / \mathrm{cm}^{2}$ dan sesudah pemberian desinfektan, yaitu $28 \mathrm{koloni} / \mathrm{cm}^{2}$, selisih -3 koloni $/ \mathrm{cm}^{2}$, prosentase $-12 \%$, lalu saat pengambilan sampel angka kuman pada pagi hari tanggal 3 Mei 2017 pada lokasi titik 1 didapatkan angka kuman sebelum pemberian desinfektan, yaitu $520 \mathrm{koloni} / \mathrm{cm}^{2}$ dan sesudah pemberian desinfektan, yaitu $53 \mathrm{koloni} / \mathrm{cm}^{2}$, selisih $467 \mathrm{koloni} / \mathrm{cm}^{2}$, prosentase $89,8 \%$, pada lokasi titik 2 didapatkan angka kuman sebelum pemberian desinfektan, yaitu $506 \mathrm{koloni} / \mathrm{cm}^{2}$ dan sesudah pemberian desinfektan, yaitu $17 \mathrm{koloni} / \mathrm{cm}^{2}$, selisih 489 koloni $/ \mathrm{cm}^{2}$, prosentase $96,6 \%$, pada lokasi titik 3 didapatkan angka kuman sebelum pemberian desinfektan, yaitu $236 \mathrm{koloni} / \mathrm{cm}^{2}$ dan sesudah pemberian desinfektan, yaitu $44 \mathrm{koloni} / \mathrm{cm}^{2}$, selisih 192 koloni $/ \mathrm{cm}^{2}$, prosentase $81,3 \%$, pada lokasi titik 4 didapatkan angka kuman sebelum pemberian desinfektan, yaitu $2.377 \mathrm{koloni} / \mathrm{cm}^{2}$ dan sesudah pemberian desinfektan, yaitu $40 \mathrm{koloni} / \mathrm{cm}^{2}$, selisih
$2.377 \mathrm{koloni} / \mathrm{cm}^{2}$, prosentase 98,3\%, pada lokasi titik 5 didapatkan angka kuman sebelum pemberian desinfektan, yaitu $450 \mathrm{koloni} / \mathrm{cm}^{2}$ dan sesudah pemberian desinfektan, yaitu $65 \mathrm{koloni} / \mathrm{cm}^{2}$, selisih 385 koloni $/ \mathrm{cm}^{2}$, prosentase $85,5 \%$, pada lokasi titik 6 didapatkan angka kuman sebelum pemberian desinfektan, yaitu $560 \mathrm{koloni} / \mathrm{cm}^{2}$ dan sesudah pemberian desinfektan, yaitu $38 \mathrm{koloni} / \mathrm{cm}^{2}$, selisih 522 koloni $/ \mathrm{cm}^{2}$, prosentase $93,2 \%$, pada lokasi titik 7 didapatkan angka kuman sebelum pemberian desinfektan, yaitu $1.112 \mathrm{koloni} / \mathrm{cm}^{2}$ dan sesudah pemberian desinfektan, yaitu $22 \mathrm{koloni} / \mathrm{cm}^{2}$, selisih $1.090 \mathrm{koloni} / \mathrm{cm}^{2}$, prosentase $98 \%$, pada lokasi titik 8 didapatkan angka kuman sebelum pemberian desinfektan, yaitu $665 \mathrm{koloni} / \mathrm{cm}^{2}$ dan sesudah pemberian desinfektan, yaitu $17 \mathrm{koloni} / \mathrm{cm}^{2}$, selisih 648 koloni $/ \mathrm{cm}^{2}$, prosentase $97,4 \%$, pada lokasi titik 9 didapatkan angka kuman sebelum pemberian desinfektan, yaitu $1.758 \mathrm{koloni} / \mathrm{cm}^{2}$ dan sesudah pemberian desinfektan, yaitu $43 \mathrm{koloni} / \mathrm{cm}^{2}$, selisih $1.715 \mathrm{koloni} / \mathrm{cm}^{2}$, prosentase $97,5 \%$.

Dilihat dari penjelasan tersebut didapatkan hasil jumlah rata-rata angka kuman lantai sebelum pemberian desinfektan, yaitu $314,8 \mathrm{koloni} / \mathrm{cm}^{2}$. Nilai tersebut melebihi dari persyaratan yang ditetapkan, yaitu 5-10 $\mathrm{koloni} / \mathrm{cm}^{2}$ pada ruang perawatan menurut Kepmenkes RI tentang Persyaratan Kesehatan Lingkungan Rumah Sakit. Persyaratan angka kuman lantai 5-10 koloni/ $\mathrm{cm}^{2}$ pada ruang perawatan mempunyai tujuan baik, yaitu sebagai salah satu upaya pencegahan penyakit menular yang disebabkan oleh mikroorganisme di ruang perawatan, sehingga dengan adanya data angka kuman lantai Ruang Parikesit kelas III sesudah pengepelan tanpa pemberian desinfektan yang mencapai rata-rata $314,8 \mathrm{koloni} / \mathrm{cm}^{2}$ menunjukkan bahwa setiap pasien, petugasdanpenunggumempunyai resiko terkontaminasi dan terinfeksi mikroorganisme tersebut.

Angka rata-rata kuman lantai setelah pemberian desinfektan adalah $22,8 \mathrm{koloni} / \mathrm{cm}^{2}$, hasil rata-rata tersebut tidak memenuhi persyaratan yang ditetapkan, yaitu 5-10 koloni $/ \mathrm{cm}^{2}$ pada ruang perawatan menurut Kepmenkes RItentang PersyaratanKesehatan Lingkungan Rumah Sakit. Data rata-rata angka kuman sesudah pemberian desinfektan yang mencapai 22,8 koloni/ $\mathrm{cm}^{2}$ dipengaruhi oleh beberapa faktor, antara lain : suhu pada ruang perawatan dibawah $25^{\circ} \mathrm{C}$, suhu tersebut merupakan suhu yang baik untuk pertumbuhan bakteri, para pengunjung yang berlalalu lalang saat diadakan pengepelan.

\section{d. Desinfektan Karbol}

Pengepelan Ruang Parikesit Kelas III Rumah Sakit TK III 04.06.01 Wijayakusuma Purwokerto menggunakan desinfektan dengan merk Wipol Karbol yang mengandung bahan aktif Pine Oil 2,5 \%. Dikemasan tercantum cara penggunaan Wipol Karbol yaitu melarutkan 2 tutup botol dengan 1 liter air (1 tutup 
botol $=10 \mathrm{ml}$ ). Dosis yang peneliti gunakan dalam pencampuran desinfektan Wipol Karbol tersebut adalah $10 \mathrm{ml}, 20 \mathrm{ml}, 30 \mathrm{ml}$ desinfektan, kemudian dilarutkan dengan 1,5 liter air akan tetapi, dosis yang digunakan dalam pencampuran desinfektan di rumah sakitadalah 10 $\mathrm{ml}$ desinfektan dilarutkan dengan 3 liter air, berarti dosis yang digunakan di Rumah Sakit TK III 04.06.01 Wijayakusuma lebih encer dari yang dianjurkan, sehingga daya bunuhnya terhadap kuman rendah. Hal ini dapat dilihat dari jumlah angka kuman lantai setelah pengepelan masih dibawah standar yang ditentukan yaitu 5-10 koloni/ $\mathrm{cm}^{2}$ untuk ruang perawatan.

e. Upaya Pengendalian Angka Kuman Lantai

Petugas kebersihan Ruang Parikesit Kelas III membersihkan lantai dengan menggunakan sapu, petugas kebersihan menyapu lantai Ruang Parikesit sebelum melakukan pengepelan, yaitu pukul 07.00 WIB, cara menyapu petugas kebersihan, yaitu dengan cara menyapu lantai yang ada kotoran, debu dan sampah, kemudian pel dengan menggunakan kain pel yang bersih dengan ukuran 40x20 cm, lalu campurkan bahan desinfektan merk Wipol Karbol dosis $10 \mathrm{ml}$ dengan 3 liter air. Bahan desinfektan Wipol Karbol ini mengandung bahan aktif Pine Oil 2,5 \% dan Creasylic acid. Metode pengepelan yang dilakukan petugas kebersihan di Ruang Parikesit Kelas III adalah pengepelan dilakukan secara manual, dengan cara horisontal bolak-balik dengan tekanan cukup. Petugas kebersihan yang ada di Ruang Parikesit Kelas III terdiri dari 1 orang yang melakukan shift pengepelan pagi dan siang. Jadwal kegiatan petugas kebersihan di Ruang Parikesit Kelas III terdiri dari 2 shift, untuk shift yang pertama pukul 07.00 WIB dan shift kedua pukul 13.00 WIB.

f. Analisis Statistik

Setelah dilakukan analisis tabel untuk mengetahui rata- rata jumlah angka kuman pada lantai Ruang Parikesit Kelas III sebelum dan sesudah pemberian desinfektan menggunakan Wipol Karbol, thap selanjutnya adalah melakukan uji statistik. Tujuan dilakukan uji statistik adalah untuk menentukan perbedaan antara jumlah angka kuman sebelum pemberian desinfektan dan sesudah pemberian desinfektan. Uji statisktik yang digunakan dalam penelitian ini adalah Uji Paired t-test dengan menggunakan SPSS versi 13.0. Hasil uji statistik didapatkan nilai thitung sebesar 2,643 dengan signifikansi 0,014 , nilai ini lebih besar dari nilai ttabel pada df 26 dengan $\alpha 0,10$ yaitu sebesar 1,315 , sehingga nilai thitung pada daerah penerimaan Ha yang artinya terdapat perbedaan antara sebelum dan sesudah. Hal tersebut dapat terjadi karena adanya penggunaan desinfektan dengan jumlah konsentrasi yang besar, sehingga kekuatan daya bunuh desinfektan terhadap kuman tinggi. Hal ini dapat diketahui dengan melihat rata-rata prosentase penurunan jumlah kuman, yaitu sebesar $6,90 \%$.

\section{Kesimpulan}

a. Rata-rata jumlah kuman lantai Ruang Parikesit Kelas III Rumah Sakit TK III 04.06.01 Wijayakusuma Purwokerto sebelum pemberian desinfektan adalah $314,8 \mathrm{koloni} / \mathrm{cm}^{2}$, hal ini menunjukkan bahwa kuman lantai di Ruang Parikesit Kelas III belum memenuhi standar persyaratan angka kuman lantai, yaitu 5-10 koloni/ $\mathrm{cm}^{2}$ untuk ruang perawatan.

b. Rata-rata jumlah kuman lantai Ruang Parikesit Kelas III Rumah Sakit TK III 04.06.01 Wijayakusuma Purwokerto sesudah pemberian desinfektan adalah 22,8 koloni/ $\mathrm{cm}^{2}$, hal ini menunjukkan bahwa kuman lantai di Ruang Parikesit Kelas III belum memenuhi standar persyaratan angka kuman lantai, yaitu 5-10 koloni/ $\mathrm{cm}^{2}$ untuk ruang perawatan.

c. Rata-rata prosentase penurunan angka kuman pada lantai Ruang Parikesit Kelas III Rumah Sakit TK III 04.06.01Wijayakusuma Purwokerto sesudah pengepelan dengan menggunakan karbol adalah 6,90 $\%$.

d. Hasil analisis statistik dengan uji t menggunakan SPSS versi 13.0 didapatkan nilai $t_{\text {hitung }}$ sebesar 2,643 dengan signifikansi 0,014 , nilai ini lebih besar dari nilai $t_{\text {tabel }}$ pada df 26 dengan $\alpha$ 0,10yaitu sebesar 1,315 (P-value $<0,10$ ), sehingga nilai $t_{\text {hitung pada }}$ daerah penerimaan $\mathrm{Ha}$ yang artinya terdapat perbedaan antara sebelum dan sesudah.

e. Pengepelan dua kali sehari dengan menggunakan Karbol sudah mampu menghambat pertumbuhan kuman lantai.

\section{Ucapan Terima Kasih}

Terimakasih disampaikan kepada pihak Rumah Sakit TK III 04.06.01 Wijayakusuma Purwokerto yang telah banyak memberikan ilmu dan masukkannya, Bapak Budi Triyantoro, ST, M.Kes, selaku dosen pembimbing Karya Tulis Ilmiah, sahabat-sahabatku dan teman-teman satu angkatan yang sudah memberikan semangat, bantuan, dan masukkan yang bermanfaat.

\section{Daftar Pustaka}

1996, PedomanTeknis pengelolaan Kualitas Lingkungan di Rumah SakitdalamPencegahan InfeksiNosokomialBukuII, Jakarta:Dirjen PPM dan PLDepkes , 1992, Keputusan Menteri Kesehatan RI Nomor : 986/ Menkes/ Per/ XI/ 1992 tentang Pesyaratan Kesehatan Lingkungan Rumah Sakit, Jakarta:Dirjen PPM dan PLDepkes

,2002, Keputusan Menteri Kesehatan RI Nomor : 1335/ Menkes/ SK/ X/ 2002 tentang 
Standar Operasional Pengambilan dan Pengukuran Sampel Kualitas Udara Ruangan Rumah Sakit, Jakarta:Dirjen PPM dan PLDepkes

, 2010, PeraturanMenteriKesehatanRINo.340/ MENKES/ PER/ III/ 2010 tentang Klasifikasi Rumah Sakit, Jakarta:Dirjen PPM dan PLDepkes

, 2009, Undang - Undang Nomor 36 Tahun 2009 tentang Kesehatan, Jakarta:Dirjen PPM dan PLDepkes , 2004, KeputusanMenteri Kesehatan RI Nomor:1204/Menkes/SK/X/2004 Tentang Persyaratan Kesehatan LingkunganRumah Sakit, Jakarta: Dirjen PPM dan PLDepkes

Azrul Azwar, 1987, Pengantar Ilmu Kesehatan Lingkungan, Jakarta: Mutiara Sumber Widya

Annisa Pratama, 2015, Skripsi Kondisi Sanitasi Ruang Rawat Inap Kelas III dan Penggunaan Desinfektan terhadap Jumlah Angka Kuman Lantai di Ruang Rawat Inap Kelas III RSUD Kota Padangsidimpuan Tahun 2015, Medan : Universitas Sumatra Utara

Brenda Ervistya Pratiwi, 2012, Skripsi Efektivitas Desinfeksi Karbol 4\% di Ruang Isolasi Barat ICU RSUD Moewardi, Surakarta : Universitas Sebelas Maret

Cahyono, Tri, 2014, Pedoman Penulisan Proposal Penelitian dan Karya Tulis Ilmiah (Edisi Revisi Ketiga), Purwokerto : Kementrian Kesehatan RI Politeknik Kesehatan Depkes Semarang Jurusan Kesehatan Lingkungan

Departemen Kesehatan RI, 1993, Persyaratan Kesehatan Lingkungan Rumah Sakit, Dirjen PPM dan PLP, Jakarta
Indonesia,Depdikbud, 1995,Kamus BesarBahasa Indonesia, Pusat Pembinaan dan PengembanganBahasaIndonesia, Jakarta:Balai Pustaka

Michael,J. Pelczar, Jr., et. al., 1988,Dasar-dasar Mikrobiologi, Jakarta: UI-Press

Nyoman Suendra, et. al., 1991, Buku Pedoman Mata Ajaran MikrobiologiLingkungan, Jakarta: Pusat PendidikanTenagaKesehatan Depkes RI

Rahma, Eka, 2015, Skripsi Penentuan Koefisien Fenol Pembersih Lantai yang mengandung Pine Oil 2,5 \% terhadap Bakteri Pseudomonas aeruginosa, Jakarta : Universitas Islam Negeri Syarif Hadayatullah

Sanropie, Djasio, 1998, Pengawasan Penyehatan Lingkungan Pemukiman, Jakarta : Pusdiknakes Depkes RI

Santjaka, Aris. 2011. Statistik Untuk Penelitian Kesehatan. Yogyakarta: Nuha Medika

Tria Widiastuti, 2008,Studi Komparasi Jumlah Kuman Sebelum dan Sesudah Pemberian Desinfektan di Ruang Perawatan Bangsal Anak RSUD Brebes, Purwokerto : Jurusan Kesehatan Lingkungan Purwokerto

Yalina, Sukma, 2013, SkripsiEfektivitas Desinfektan Pine Oil 1,5\% + Creasylic Acid dan Pine Oil 2,5 \% terhadap jumlah Angka Kuman pada Lantai Ruang Rawat Inap Rumah Sakit Umum Deli Medan, Medan : Universitas Sumatra Utara

Yusda Dhani Kusuma, 2009,Studi Angka Kuman pada Lantai di Ruang Melati RSUD Prof. Dr. Margono Soekarjo Purwokerto, Purwokerto : Jurusan Kesehatan Lingkungan Purwokerto 